\title{
On the Provenance of Slaves in Mecca during the Time of the Prophet Muhammad HEND GILLI-ELEWY
}

Interdisciplinary General Education Department, California Polytechnic State University, Pomona, Pomona, Calif.; e-mail:

hgillielewy@cpp.edu

doi:10.1017/S0020743816001239

There is hardly a source on early Islam that does not mention slaves in one way or another. They were ubiquitous companions of events, occasions, and incidences. But they played marginal roles in historical accounts. The numerous fragments of information, anecdotes, and offhand references concerning slaves during the rise of Islam call to be collected and analyzed to piece together a picture of various aspects of slavery during this period. References to slaves are especially prevalent in legal texts, as slaves provided useful cases to Muslim jurists to think through legal questions. The discussion of examples of slaves, $w a l \bar{a}^{2}$ (clientele relationships), and manumission in hadith, exegesis, and jurisprudence has not only provided significant insight into the legal status of slaves, but has also helped scholars to develop a methodology for verifying and evaluating the source material itself. ${ }^{1}$ In this essay, I examine pieces of information available in historical and biographical works on early Islam to address the question of the provenance and procurement of slaves in Mecca, Medina, and the Hijaz during the time of the Prophet Muhammad. ${ }^{2}$ Reconstructing this story involves dealing with narratives transmitted in various short, spurious, and often unrelated accounts. The source material for early Islam is, as is often pointed out, problematic and at times contradictory. It is laced with topoi and leitmotifs, and frequently proves tendentious, reflecting the opinions and biases of those who wrote them more than what actually happened. Nevertheless, reading beyond the topoi, leitmotifs, and tendentiousness, we find that "in the Traditions there is an undeniable core of "fact", 3 with which we can work and assume to be valid until shown to be false.

A look at the lists of slaves and ex-slaves belonging to Muhammad in Ibn $\mathrm{Sa}^{\mathrm{c}} \mathrm{d}$ and al-Tabari, as well as the lists of the slaves who participated in the battle of Badr (624), reveals a diverse picture. ${ }^{4}$ Apart from the large number of enslaved Arabs, the sources identify Abyssinians (used as a general term for East Africans), Persians, Nubians, Copts, and Byzantines. ${ }^{5}$ Although Arab slaves were the majority, the number of African slaves (about one-third of those listed) was also relatively high. ${ }^{6}$ What led to such a diverse offering of slaves in Mecca of the 6th and 7 th centuries?

The vast majority of slaves in pre- and early Islamic times seem to have been Arab prisoners of war, victims of intertribal warfare reminiscent of the ayām al- 'arab (the battle days of the Arabs in pre-Islamic Arabia). ${ }^{7}$ These captives were enslaved if the ransom on them went unpaid. Women and children often accompanied men on these intertribal raids and battles- the Quraysh during the battle of Uhud still seem to have engaged in this custom-and thus could also become captives and slaves. The women were either married off or served as concubines; children were not to be separated from their mothers. ${ }^{8}$ The marriages to captive women do not seem to have been equal to marriages with free women. For example, when the children of a Ghifari captive, Salma, were insulted as "children of a prisoner," her husband, 'Urwa b. al-Ward, 
returned to her family so that they would marry her back to him as an equal woman. ${ }^{9}$ Under Islam, captives of war continued to constitute a main source of enslavement, with some legal restrictions and modifications. The creation of the umma in Medina implemented a principle of classification opposing believers and nonbelievers. Under this new division Muslims could not be enslaved, and the captives acquired through war were part of the spoils (ghanima) to be distributed to those eligible to receive them. Captives of war could also be used to free Muslim prisoners held by enemy armies, or could be freed for a ransom or killed. The prisoners could also buy their freedom. ${ }^{10}$

To further fill in the picture of the diverse slave population in Arabia, it is necessary to see Mecca's relationship with Yemen and Ethiopia at the time in a larger geopolitical context. Arabia in the century before Muhammad was a site of contestation over trade routes between the Persian and Byzantine Empires, the latter allied with the Abyssinian Kingdom. This power struggle was often carried out in the south, in Yemen and Hadramawt, and led to a strong presence of Abyssinian forces in southern Arabia. In 523 the Negus (the Christian King of Abyssinia) is supposed to have sent 70,000 (a figure that surely is to be understood figuratively) Abyssinians to depose King Dhu Nuwas and conquer southern Arabia. ${ }^{11}$ A few years later in 570 Abraha led a famous expedition against Mecca and the Ka ${ }^{c}$ ba during the Year of the Elephant ( ${ }^{c} \bar{a} m$ al-fill). ${ }^{12}$ Ultimately, one of the consequences of the military conquest of southern Arabia was that it propelled the influx of a large number of Abyssinians to Southern Arabia and the Hijaz, ${ }^{13}$ who in turn represented a large pool of potential slaves once the Abyssinians were defeated by the Persians in $575 .{ }^{14}$ Some of those who were enslaved seem to have been transported to Persia. ${ }^{15}$ It is thus probable that many of the east African slaves in the Hijaz referenced in the sources became slaves through the military conflicts with the Abyssinians during the second half of the 6th century. The enslavement of Abyssinians in Arabia was predominantly a consequence of war, not the international slave trade, which would be the case in later centuries.

The second source of slaves was the slave trade. Mecca is traditionally regarded as a significant commercial city in the Hjaz and, situated as it was along major international trade routes, even an international trading center. As Mahmood Ibrahim notes, "Mecca's existence depended primarily on its location near the most important trade route in western Arabia which linked the surplus-producing region of Yemen with Syria."16 Beginning in the second half of the 6th century the Meccans maintained control over the trade routes and dominated the international trade network. ${ }^{17}$ Mecca's economic development is usually attributed to its favorable geographical location, the presence of the holy $\mathrm{Ka}^{\mathrm{c}} \mathrm{ba}$, and the various security policies related to the Haram especially and the three holy months, from which foreigners, travelers, and pilgrims benefitted. ${ }^{18}$ Since the late 1980s, this representation of Mecca has been revisited to varying degrees by different scholars, especially Patricia Crone, whose revisionist work has tried to reevaluate the sources and completely deconstruct this image of Mecca. Crone's work itself has been criticized, notably by R. B. Serjeant, and has polarized the discussion on Meccan trade. ${ }^{19}$ Apart from H. Lammens and W. M. Watt, scholars such as M. J. Kister, M. A. Shaban, F. E. Peters, Robert Simon, Fred Donner, Ibrahim Mahmood, and others have laid the foundation for a more complex and differentiated understanding of Hijazi trade during the 6 th and 7 th centuries. ${ }^{20}$

The sources do attest to Mecca and the Hijaz engaging in trade with neighboring regions during the 6th century. ${ }^{21}$ This trade may have emerged out of the need to 
satisfy local demand for cloths, weapons, and other provisions, but it also created the opportunity for local elites to acquire non-Arab slaves. ${ }^{22}$ The markets in 'Ukaz, Dhu al-Majaz, and Majanna, as well as those in Mecca and Medina, emerged as important points of sale and distribution for slaves. The sources also leave us the names of Arabic slave merchants (nakhkhās). ${ }^{23}$ However, nothing in the sources indicates that Mecca was "un des plus important marchés d'esclaves" (one of the most important slave markets), as Henri Lammens put it. ${ }^{24} \mathrm{Al}$-Azraqi's description of the pilgrimage sites and their markets does not suggest that Mecca had a predominant role in the slave trade..$^{25}$

The source material also does not provide any indication that slaves were brought directly to Mecca and the Hijaz in masses. The importation of Abyssinian slaves mentioned in the context of the east African ivory and gold trade ${ }^{26}$ does not seem to have occurred via the direct sea route to the Meccan port of Shu ayba, but rather through Yemen. ${ }^{27}$ East African slaves were a common commodity that reached Mecca and the Hijaz through Yemen, secured by the charters acquired by Hashim b. 'Abd Manaf (Muhammad's great grandfather and head of the Qurayshi clan of Hashim) and others. The reason for the slave trade's apparently limited scale in Mecca during the first century of Islam might relate to the fact that converted Arabs in Arabia could no longer be enslaved. As a result of the rapid Muslim conquests, the borders of enslavement were pushed further and further away.

Apart from the main two sources of enslavement—slave trade and warfare-other causes of enslavement are mentioned in pre-Islamic Arabia, such as debt slavery, sacrificial enslavement, selling oneself or one's children, kidnap, and enslavement as punishment. Muhammad prohibited debt as a source of enslavement, just as he banned selling one's own children and sacrificial enslavement to deities and shrines, as well as tasyīb (unconditional manumission). ${ }^{28}$ Several factors may have prompted Muhammad to make such a prohibition, including the need to distance Islam and Islamic practices from pre-Islamic pagan traditions of sacrifice to pagan deities. Apart from captivity through warfare, the only other source of enslavement that was recognized by Islam was birth - in other words, children of slaves became slaves. ${ }^{29}$

In sum, medieval Arabic sources on slavery-fragmentary, cursory, and anecdotal as they are-document a significant number of accounts, events, and transactions. Their aggregation can help us to piece together the complex and dynamic picture of early Islamic slavery, the formation of which involved the Muslim community negotiating new Islamic ideals and practices into pre-Islamic conditions and institutions. Arabs constituted the majority of slaves during the rise of Islam, while African slaves were the largest non-Arab group. Though Mecca became a prominent international commercial center in the mid-6th century, its role as a major trade center for slaves seems to have developed later. Amongst other reasons, this lag might relate to the fact that rapid conquests and Islamization of Arabia reduced the number of available enslaved captives of war and pushed the borders of enslavement further away.

\section{NOTES}

\footnotetext{
${ }^{1}$ For an example, see Ulrike Mitter's matn-cum-isnad methodology in "Unconditional Manumission of Slaves in Early Islamic Law: A hadith Analysis," Der Islam 78 (2001): 35-73. See also works by Irene Schneider and Kecia Ali.
} 
${ }^{2}$ In this essay, I only cover information contained in the sīra of Ibn Ishaq (d. ca. 767) in Abu Muhammad 'Abd al-Malik ibn Hisham (d. 834), Kitab Sirat Rasul Allah, ed. F. Wüstenfeld (Göttingen, 1859-60); Abu 'Abd Allah Muhammad b. 'Umar al-Waqidi (d. 823), Kitab al-Maghazi, ed. M. Jones, 3 vols. (London, 1965, 1984); Abu 'Abd Allah Muhammad ibn Sa'd (d. 845), al-Kitab al-Tabaqat al-Kabir, ed. E. Sachau, 9 vols. (Leiden, 1905-40); Abu Jacfar Muhammad b. Jarir al-Tabari (d. 923), Kitab al-Rusul wa-l-Muluk; and Abu Muhammad 'Abd Allah b. Muslim ibn Qutayba (d. 889), Kitab al-Ma'arif, ed. Muhammad Isma i il 'Abd Allah al-Sawi (Beirut: n.p., 1970). I also draw on Muhammad b. 'Abd Allah al-Azraqi (d. ca. 864), Kitab Akhbar Makka wa-Ma Ja'a fiha min al-Athar, ed. F. Wüstenfeld, vol. 1 (Leipzig, 1858); and two works by Ahmad b. Yahya al-Baladhuri (d. 892): Kitab Futuh al-Buldan, ed. M. J. de Goeje (Leiden, 1866), and Kitab Ansab al-Ashraf, ed. S. D. F. Goitein and M. Schloessinger, 6 vols. (Jerusalem, 1938).

${ }^{3}$ R. B. Serjeant, "Review: Meccan Trade and the Rise of Islam: Misconceptions and Flawed Polemics," Journal of the American Oriental Society 110 (1990): 472.

${ }^{4}$ Ibn Sa'd, al-Kitab al-Tabaqat al-Kabir, 1:2:180; al-Tabari, Kitab al-Rusul, 1778-81. On Badr, see Ibn Hisham, Kitab Sirat Rasul Allah, 486-503; and the list in W. Montgomery Watt, Muhammad at Medina (Oxford: Oxford University Press, 1956), 344.

${ }^{5}$ Arabs: Ibn Qutayba, Kitab al-Macarif, 63; Ibn Sacd, al-Kitab al-Tabaqat al-Kabir, 1:2:179-80; al-Tabari, Kitab al-Rusul, 1778, 1780. Abyssinians: al-Tabari, Kitab al-Rusul, 1778, 1780; Ibn Sa'd, al-Kitab al-Tabaqat al-Kabir 3:1:167; Ibn Hisham, Kitab Sirat Rasul Allah, 486. Persians: al-Tabari, Kitab al-Rusul, 1779, 1940; Ibn Hisham, Kitab Sirat Rasul Allah, 486. Nubians: Ibn Sa`d, al-Kitab al-Tabaqat al-Kabir 1:2:180; alTabari, Kitab al-Rusul, 1781; Ibn Hisham, Kitab Sirat Rasul Allah, 999. Copts: al-Tabari, Kitab al-Rusul, 1781; Ibn Sa'd, al-Kitab al-Tabaqat al-Kabir, 8:153. Byzantine: Ibn Sa'd, al-Kitab al-Tabaqat al-Kabir, $3: 1: 26$

${ }^{6} \mathrm{Six}$ out of ca. twenty slaves and freed slaves of Muhammad were either fully or partially of African descent. Al-Tabari Kitab al-Rusul, 1778, 1780-81; Ibn Sa`d, al-Kitab al-Tabaqat al-Kabir, 1:2:180, 184; Ibn Hisham, Kitab Sirat Rasul Allah, 486, 999. On Muhammad's foster mother, see Rotter, Die Stellung, 26; and n. 1. Four out of twelve of the slaves of the fighting muhäjirūn in Badr were black. Ibn Hisham, Kitab Sirat Rasul Allah, 486-503. This high number of African slaves is also confirmed by Azraqi, Kitab Akhbar Makka, 464, 486; and Muhammad ibn Habib, Muhabbar, ed. I. Lichtenstader (Beirut: n.p., 1943), 306ff.

${ }^{7}$ See Rotter, Die Stellung, 26; Th. W. Juynboll, "Abd," in Encyclopaedia of Islam, First Edition (1913-1936), ed. M. Th. Houtsma, T.W. Arnold, R. Basset, and R. Hartmann, accessed 11 October 2016, http://dx.doi.org/10.1163/2214-871X_ei1_COM_0006; and Robertson Smith, Kinship and Marriage in Early Arabia (London: Adam and Charles Black, 1907), 295. On the literary motive of the ayām al- 'arab, see Werner Caskel, “Aijām al-'arab: Studien zur altarabischen Epik,” Islamica 3 (1930): 1-99.

${ }^{8}$ Ibn Hisham, Kitab Sirat Rasul Allah, 557; Waqidi, Kitab al-Maghazi, 2:523.

${ }^{9}$ Al-Waqidi, Kitab al-Maghazi, 1:376.

${ }^{10} \mathrm{On}$ the first prisoners of war taken by the Muslims that were used to ensure the freedom of two Muslims, see Ibn Hisham, Kitab Sirat Rasul Allah, 424-26; and al-Waqidi, Kitab al-Maghazi, 1:15, 17. On the case of a female slave who negotiated her liberation, see Ibn Hisham, Kitab Sirat Rasul Allah, 729.

${ }^{11}$ On this, see al-Tabari, Kitab al-Rusul, 925-37; Ibn Hisham, Kitab Sirat Rasul Allah, 26; and M.J. Kister, "Some Reports Concerning Mecca from Jāhiliyya to Islam," Journal of the Economic and Social History of the Orient 15 (1972): 61-91.

${ }^{12}$ Ibn Hisham, Kitab Sirat Rasul Allah, 31-38. See also Qur'an (CV) (Surat al-Fil); Irfan Kawer Shahid, "Two Qur'ānic Sūras: al-Fịl and al-Quraysh," in Studia Arabica et Islamica: Festschrift für Ihsān 'Abbās, ed. W. al-Qadi (Beirut: American University of Beirut, 1981), 429-36; Irfan Kawer Shahid, "The Kebra Negast in the Light of Recent Research," in Byzantium and the Semitic Orient before the Rise of Islam, ed. I. Shahid (London: Variorium, 1988), 169.

${ }^{13}$ Ibn al-Dhi' ba in Ibn Hisham, Kitab Sirat Rasul Allah, 27; al-Tabari, Kitab al-Rusul, 927; A. F. L. Beetson, "Abraha," in Encyclopaedia of Islam, Second Edition, accessed 11 October 2016, http://dx.doi.org/10.1163/ 1573-3912_islam_SIM_0149.

${ }^{14}$ Al-Tabari reports large-scale enslavement of Abyssinians by the new Himyari king Sayf b. Dhi Yazan and the Persian Wahriz; Kitab al-Rusul, 957.

${ }^{15}$ Arthur Christensen, L'Iran sous les Sassanides (Copenhagen: E. Munksgaard, 1944), 126-27.

${ }^{16}$ Mahmood Ibrahim, "Social and Economic Conditions in Pre-Islamic Mecca," International Journal of Middle East Studies 14 (1982): 343; Ibrahim, Merchant Capital and Islam (Austin, Tex.: University of Texas Press, 1990). 
${ }^{17}$ See W. Montgomery Watt, Muhammad at Mecca (Oxford: Oxford University Press, 1953), 3; and Watt, "Makka," in Encyclopaedia of Islam, 2nd ed., accessed 11 October 2016, http://dx.doi.org/10.1163/ 1573-3912_islam_COM_0638.

${ }^{18}$ See Watt, "Makka”; and M.J. Kister, "Some Reports Concerning Mecca,” 76. Crone, Meccan Trade, 196, doubts the importance of the shrine.

${ }^{19}$ R.B. Serjeant, "Review: Meccan Trade," 472-86. See also Gene W. Heck's rather reconciliatory article, “"Arabia without Spices': An Alternate Hypothesis,” Journal of the American Oriental Society 123 (2003): $547-76$.

${ }^{20}$ See Watt, Muhammad at Mecca; Henri Lammens, La Mecque à la vielle de l'Hégire, in Mélanges de l'Université St.-Joseph (Beirut, n.p., 1924), 118; M.J. Kister, "Mecca and Tamīm (Aspects of Their Relations)," Journal of the Economic and Social History of the Orient 8 (1965): 113-63; Kister, "Some Reports"; M. Shaban, Islamic History: A New Interpretation (London: Cambridge University Press, 1971); Fred M. Donner, "Mecca's Food Supplies and Muhammad's Boycott," Journal of the Economic and Social History of the Orient 20 (1977): 249-66; Donner, The Early Islamic Conquests (Princeton, N.J.: Princeton University Press, 1981); R. Simon, Meccan Trade and Islam: Problems of Origin and Structure (Budapest: n.p., 1989); F. E. Peters, "The Commerce of Mecca Before Islam," in A Way Prepared: Essays on Islamic Culture in Honor of Richard Bayly Winder, ed. F Kazemi and R. D. McChesney (New York: New York University Press, 1988); Ibrahim, Merchant Capital and Islam.

${ }^{21}$ Hashim 'Abd Manaf (Muhammad's great grandfather) is said to have traveled to Abyssinia, then Yemen, Persia, and Syria, to acquire letters of safe conduct in order to secure trade with those regions; Ibn Hisham, Kitab Sirat Rasul Allah, 87; al-Azraqi, Kitab Akhbar Makka, 4:35; Kister, "Some Reports," 61-62.

${ }^{22}$ On weapons from Abyssinia and Syria, see F. W. Schwarzlose, Die Waffen der alten Araber aus ihren Dichtern dargestellt (Leipzig, 1886), 131. On the exchange of prisoners for horses and weapons, see Waqidi, Kitab al-Maghazi, 2:523. On cloths from Yemen, see Crone, Meccan Trade, 150-51. On slaves, see Ibn Sa'd, al-Kitab al-Tabaqat al-Kabir, 3:1:164; Ibn Qutayba, Kitab al-Ma'arif, 114; Ibn Hisham, Kitab Sirat Rasul Allah, 140.

${ }^{23}$ Ahmad b. 'Ali b. Muhammad Ibn Hajar al-'Asqalani, al-Isaba fi Tamyiz al-Sahaba wa-ma'ahu al-Isti ${ }^{c} a b$ fi Asma' al-Ashab li-Abi 'Umar Yusuf b. 'Abd Allah b. Muhammad b. 'Abd al-Barr an-Namarri (Cairo: n.p., 1939), 4:32-33; Ibn Qutayba, Kitab al-Ma'arif, 250.

${ }^{24}$ Henri Lammens, L'Arabie occidentale avant l'hégire (Beirut: Imprimerie Catholique, 1928), 12.

${ }^{25}$ Azraqi, Kitab Akhbar Makka, 129-30.

${ }^{26}$ Lammens, La Mecque, 300; Lammens, L'Arabie, 12.

${ }^{27}$ See Rotter, Die Stellung, 24, 29-30; and Crone: Meccan Trade, 80. On the relationship of Mecca to Shu'ayba, see G.R. Hawting, "The Origin of Jedda and the Problem of al-Shu'ayba," Arabica 31 (1984): 318 26. Trade with Yemen is also attested to in Azraqi, Kitab Akhbar Makka, 99, 175; Kister, "Some Reports," 62, 64, 72; and Ibn Sa'd, al-Kitab al-Tabaqat al-Kabir, 3:1:244, 232. On east African slaves, see Murray Gordon, Slavery in the Arab World (New York: New Amsterdam Books, 1989), 18.

${ }^{28}$ On the prohibition of pre-Islamic practices of enslavement, see Hans Müller, "Sklaven," in Wirtschaftsgeschichte des Vorderen Orients in islamischer Zeit, ed. B. Spuler (Leiden: Brill, 1977), 1:59. On tasyīb, see the extensive work of Mitter, "Unconditional Manumission."

${ }^{29}$ An exception was the status of the umm walad and her children; see Hans Müller, "Sklaven," 60, 63; Juynboll, Handbuch, 206; and J. Schacht, "Umm al-Walad," in Encyclopaedia of Islam, Second Edition, accessed 11 October 2016, http://dx.doi.org/10.1163/1573-3912_islam_COM_1290. 